\title{
Allopolyploid speciation of Calypogeia sphagnicola (Jungermanniopsida, Calypogeiaceae) based on isozyme and DNA markers
}

\author{
Katarzyna Buczkowska $\cdot$ Jakub Sawicki • \\ Monika Szczecińska $\cdot$ Henryk Klama $\cdot$ \\ Alina Bączkiewicz
}

Received: 16 May 2011/Accepted: 6 November 2011/Published online: 2 December 2011

(c) The Author(s) 2011. This article is published with open access at Springerlink.com

\begin{abstract}
Calypogeia sphagnicola is one of nine species of the genus Calypogeia known in Europe. Occurrence of the species is closely connected with peat bogs. Nowadays, two forms of this species are distinguished-C. sphagnicola f. sphagnicola and C. sphagnicola f. paludosa. The results of the present study, based on two classes of markers-isozymes and sequences of chloroplast genom $(t r n \mathrm{H}-p s b \mathrm{~A}, r p o \mathrm{C} 1)$ - unanimously support the genetic differentiation within the taxon and show that the presentday forms represent genetically distinct species. Phylogenetic analysis resolved two lineages that correspond with the present-day forms with high bootstrap support, which differ in ploidy level: C. sphagnicola f. sphagnicola is haploid, whereas C. sphagnicola f. paludosa is a diploid form. Allopolyploid origin of the diploid form was revealed by the isozyme pattern. Nei's genetic distance between the two present-day forms of $C$. sphagnicola was 0.472. The forms in Poland have an allopatric pattern of geographic distribution: C. sphagnicola f. sphagnicola occurs exclusively in the lowlands of the northern part of the country on raised peat bogs, whereas $C$. sphagnicola
\end{abstract}

K. Buczkowska $(\bowtie) \cdot$ A. Bączkiewicz

Department of Genetics, Institute of Experimental Biology,

Adam Mickiewicz University, ul. Umultowska 89,

61-614 Poznan, Poland

e-mail: androsac@amu.edu.pl

J. Sawicki · M. Szczecińska

Department of Botany and Nature Protection,

University of Warmia and Mazury in Olsztyn, Plac Łódzki 1,

10-728 Olsztyn, Poland

\section{H. Klama}

Institute of Environmental Protection and Engineering,

University of Bielsko-Biała, Willowa 2,

43-309 Bielsko-Biała, Poland f. paludosa is found only in the mountains of southern Poland, mainly in the subalpine zone, where it grows on Sphagnum-Polytrichum hummocks on the upper part of north-facing slopes. Plants regarded in this study as $C$. sphagnicola $\mathrm{f}$. sphagnicola morphologically correspond to the syntype specimen of $C$. sphagnicola.

Keywords Liverworts - Calypogeia - Isozymes · rpoC1 . trn $\mathrm{H}-p s b \mathrm{~A} \cdot$ Species speciation

\section{Introduction}

Liverwort taxonomists have at their disposal only a limited number of good diagnostic qualitative traits because of the reduced, compared to angiosperms, morphology of the gametophyte, which dominates in the life cycle of bryophytes. The overwhelming majority of features available for study are quantitative (meristic) traits that have a continuous phenotypic range. Quantitative traits are often polygenic and may also be significantly influenced by environmental factors; hence, in some cases, diagnostic differences between species can be overlooked. For this reason, some species described in the last century on the basis of morphological criteria were too broadly defined and included some unrecognized species, e.g., Conocephalum conicum (L.) Dumort. (Szweykowski et al. 2005). Recently, classical taxonomic traits based on morphology have been supplemented with genetic markers that, in contrast with meristic traits, are not influenced by environmental changes; therefore, they are treated as an important source of taxonomic information. In liverworts, taxonomy based on genetic markers, e.g., isozymes (among others, Szweykowski and Krzakowa 1979; Bischler and Boisselier-Dubayle 2000) and molecular markers (Boisselier-Dubayle et al. 1995; 
Szweykowska-Kulińska et al. 2002; Wachowiak et al. 2007; Heinrichs et al. 2010; Kreier et al. 2010), allows to define species more precisely than was possible on the basis of classical methods only. The application of isozyme and molecular markers in studies on the genus Calypogeia Raddi revealed the presence of plants genetically distinct from the well-known and accepted species occurring in Europe. These plants probably represent new taxa, unrecognized until now. Two genetically distinct groups were recognized within the complex of $C$. fissa (L.) Raddi (Buczkowska 2004a) and C. muelleriana (Schiffn.) Müll.Frib. (Buczkowska and Bączkiewicz 2011; Buczkowska and Dabert 2011). Calypogeia sphagnicola (Arn. \& Perss.) Warnst. and Loeske seems to be another example of a liverwort species defined too broadly.

Calypogeia is a large genus of leafy liverworts of wide geographic distribution with about 90 described species (Schuster 1969). The genus is one of the most difficult groups of liverworts (Schuster 1969; Szweykowski 2006). The delimitation of Calypogeia species has often been difficult because of the lack of distinctive morphological characters, and the presence of environmentally induced modifications and atypical forms. Moreover, some European species of Calypogeia have a wide Holarctic distribution, and taxonomic controversies may also arise from heterogeneity and the possibility of hidden genetic differentiation within the geographic range (Buczkowska 2004b). According to Schuster (1969), direct adaptation of the Flora compiled for one geographic region to the material from another region can cause difficulties.

Calypogeia sphagnicola is one of nine species of the genus Calypogeia known so far in Europe (Grolle and Long 2000). The species has a bipolar pattern of geographic distribution. In the northern hemisphere it is widely distributed in northern and central Europe, the northern part of North America and in Asia (Turkey and Japan), whereas it is rare in the antipodal regions (Schuster 1969; Damsholt 2002). It is a monoecious, frequently fertile species, largely restricted to peat bogs, where it creeps over Sphagnum spp. hummocks and among them. The occurrence of C. sphagnicola in peat bogs is a diagnostic feature for this species (Schuster 1969). Initially, two different species were described whose occurrence was connected with peat bogs: C. sphagnicola (Arnell 1902) and C. paludosa (Warnstorf 1906). However, Müller (1913-1916) reduced the second one to the synonymy of $C$. sphagnicola. In spite of narrow environmental requirements, $C$. sphagnicoala shows a considerable morphological variation, caused mainly by the amount of light and moisture available (Schuster 1969; Damsholt 2002). The three most evident phenotypes were described by Schuster (1969) as forms of this species: $C$. sphagnicola f. sphagnicola-the typical form, characterized by the small size of plants [0.5-1.8 (2) $\mathrm{mm}$ wide], the presence of gemmiparous shoots and oil bodies composed of 1-4 (5-6) globules; $C$. sphagnicola f. paludosa (Warnst.) Schust.-distinguished by larger plants (2.0-2.9 mm wide) with oil bodies formed of more numerous segments (7-12), never with gemmae; $C$. sphagnicola f. bidenticulata Schust.- the form characterized by moderately vigorous plants (1.5-2.0 mm wide) without gemmae and usually with bidentate leaves with oil bodies of 6-12 (16) segments, limited in occurrence to North America.

In Europe, two forms-C. sphagnicola $\mathrm{f}$. sphagnicola and C. sphagnicola f. paludosa-were reported from Nordic countries by Damsholt (2002) and from Poland by Szweykowski (2006). Szweykowski (2006) pointed out differences in geographic distribution between both forms: the typical form is widespread in the lowlands of the northern part of Poland, where it is restricted to raised peat bogs, whereas it is very rare in the mountain regions. On the contrary, C. sphagnicola f. paludosa occurs mainly in the mountains of southern part of the country, where it is bound to Sphagnum-Polytrichum hummocks and very rarely occurs in the lowlands. Preliminary isozyme and biometrical studies showed two distinct groups of genotypes correlated with the presence or absence of gemmae, and suggested that the above forms of C. sphagnicola can represent genetically distinct species (Buczkowska et al. 2009).

Irrespective of geographic region, only one chromosome number $(n=18)$ is known for C. sphagnicola (Müller 1951-1958; Newton 1973; Inoue 1976). The same chromosome number was recorded in Poland (Buczkowska et al. 2004); however, differences in geographic distribution of C. sphagnicola forms noted by Szweykowski (2006) indicate that only one form (C. sphagnicola f. paludosa) was analyzed. In most cases it is not clear which form the chromosome counts refer to in the above-cited authors, but at least in Poland it seems likely that only C. sphagnicola f. paludosa has been assessed.

In the present study, we use two classes of markers: isozymes and DNA sequences to assess the level of genetic diversity between two forms: $C$. sphagnicola $\mathrm{f}$. sphagnicola and C. sphagnicola f. paludosa. Our aim is to verify the hypothesis that both forms represent separate species and to develop markers that could be useful for identification of plants belonging to each species, not only on the basis of fresh material but also material from herbarium collections. Additionally, flow cytometry was applied to estimate the ploidy level of the examined forms.

\section{Materials and methods}

Plant material

Samples of the studied species were collected from different regions of Poland. In total, 59 samples from 16 
populations were examined by means of isozyme analysis: 31 samples of $C$. sphagnicola f. sphagnicola and 28 samples of C. sphagnicola f. paludosa (Table 1). Plants were initially identified on the basis of morphological traits and oil body characters according to Szweykowski (2006). Plants classified as $C$. sphagnicola $\mathrm{f}$. sphagnicola were small, had gemmiparous shoots and oil bodies mostly undivided or formed of 2-3 (4) segments, whereas plants classified as $C$. sphagnicola $\mathrm{f}$. paludosa were bigger, had no gemmae and more segmented (5-10) oil bodies. Each sample was divided into two parts: one was deposited as a voucher in the POZW Herbarium, whereas the other was used for analyses. A total of 350 gametophytes (shoots) were examined (4-7 shoots from each sample) in isozyme analysis. Moreover, 28 samples of C. azurea Stotler \& Crotz, the same as used by Buczkowska and Baczkiewicz (2011), were included in the isozyme study as reference species.

Next, the plants identified on the basis of isozyme pattern were used for DNA extraction. A total of 21 samples were studied: 5 of $C$. sphagnicola f. sphagnicola, 4 of
C. sphagnicola f. paludosa and 3 samples each from the other Calypogeia species: C. azurea, C. neesiana (Massal. \& Carestia) Müll. Frib., C. integristipula Steph. and C. suecica (Arnell \& J.Perss.) Müll.Frib. Two samples of Tritomaria quinquedentata (Huds.) $\mathrm{H}$. Buch were used as an outgroup in DNA analysis (Table 2).

Isozyme analysis

Electrophoretic separation of isozymes was conducted according to the procedure described in detail by Wendel and Weeden (1989). Crude cell extract was prepared by homogenization of one stem in $40 \mu$ of extraction buffer (Gottlieb 1981). Isozymes were separated in $10 \%$ starch gel slabs using three buffer systems: Tris-citrate $\mathrm{pH}$ 8.2/lithium-borate $\mathrm{pH} 8.3$ (GOT, GDH, EST, PGI), morpholinecitrate $\mathrm{pH} 6.1$ in dilution of electrode buffer 1:14 (MDH, PGD) and Tris-histidine pH 7.0 (PGM, ME). In the enzymes with multiple loci, the fastest migrating bands were numbered as 1 and the slower as 2 (i.e., $M d h-1, M d h-2$ ). Alleles were labeled according to Buczkowska et al.

Table 1 Localities of the populations of C. sphagnicola used for isozyme studies

\begin{tabular}{|c|c|c|}
\hline $\begin{array}{l}\text { Population } \\
\text { no. }\end{array}$ & Locality & POZW no. of studied samples ${ }^{\mathrm{a}}$ \\
\hline \multicolumn{3}{|c|}{ C. sphagnicola f. sphagnicola } \\
\hline 1 & NW Poland, Pomorskie Province, Duże Sitno peat bog & $\begin{array}{l}42270,42286,42343,42346 \\
\quad 42348\end{array}$ \\
\hline 2 & $\begin{array}{l}\text { NW Poland, Pomorskie Province, peat mat in the littoral zone of Lake Wałachy near } \\
\text { Wdzydze }\end{array}$ & $\begin{array}{l}42243,42244,42282,42284 \\
42287\end{array}$ \\
\hline 3 & $\begin{array}{l}\text { NW Poland, Pomorskie Province, peat mat in the littoral zone of Lake Małe Katarzynki near } \\
\text { Borowy Młyn }\end{array}$ & $42337,42261,42245,42344$ \\
\hline 4 & NW Poland, Pomorskie Province, Kościerzyna, Krwawe Doły peat bog near Lake Chądzie & $42267,42263,42269, \mathrm{CS} 1402$ \\
\hline 5 & $\begin{array}{l}\text { NE Poland, Podlaskie Province, Wigierski National Park, peat mat in the littoral zone of Lake } \\
\text { Sucharek near Suwałki }\end{array}$ & 30944,30913 \\
\hline 6 & NW Poland, Pomorskie Province, Lake Czyste peat bog near Płocice & $42283,42342,42266$ \\
\hline 7 & $\begin{array}{l}\text { NE Poland, Warmińsko-Mazurskie Province, peat mat in the littoral zone of Godle lake near } \\
\text { Ełk }\end{array}$ & 41711 \\
\hline 8 & NE Poland, Podlaskie Province, peat bog around Lake Druce near Sejny & $30910,31026,32433,32434$ \\
\hline 9 & NE Poland, Warmińsko-Mazurskie Province, Mechacz Wielki peat bog reserve near Gołdap & $32431,32430,32429$ \\
\hline \multicolumn{3}{|c|}{ C. sphagnicola f. paludosa } \\
\hline 10 & SE Poland, Bieszczady Mts, Lutowiska, peat bog Tarnawa Wyżnia, $670 \mathrm{~m}$ a.s.l. & $34837,34839,34843$ \\
\hline 11 & $\begin{array}{l}\text { S Poland, Tatra Mts, E slope of Mt. Żółta Turnia, sphagnum-polytrichum hummocks, } \\
1,687 \mathrm{~m} \text { a.s.l. }\end{array}$ & $41168,41170,41172,41174$ \\
\hline 12 & S Poland, Tatra Mts, peat bog Toporowy Staw Wyżni, 1,110 m a.s.l. & $\begin{array}{l}41142,41148,41171,41723 \text {, } \\
\quad 41726\end{array}$ \\
\hline 13 & S Poland, Tatra Mts, Pańszczyca Valley, peat bog Wielka Pańszczycka Młaka, 1,274 m a.s.l. & $\begin{array}{l}41137,41173,41174,41175 \\
\quad 41176,42277\end{array}$ \\
\hline 14 & S Poland, Izerskie Mts, peat bog reserve Torfowiska Doliny Izery, $825 \mathrm{~m}$ a.s.l. & $35110,35115,35187$ \\
\hline 15 & S Poland, Tatra Mts, N slope of Mt Ornak, sphagnum-polytrichum hummocks, 1,700 m a.s.l. & $41722 \mathrm{a}, 41722 \mathrm{~b}, 41722 \mathrm{c}, 41722 \mathrm{~d}$ \\
\hline 16 & $\begin{array}{l}\text { S Poland, Beskid Żywiecki Mts, Mt Babia Góra, sphagnum-polytrichum hummocks, 1,560 m } \\
\text { a.s.l. }\end{array}$ & $39412,39503,39022$ \\
\hline
\end{tabular}

a The vouchers are deposited in the POZW Herbarium 
Table 2 Localities of the samples of Calypogeia species used for DNA studies and GenBank accession numbers

\begin{tabular}{|c|c|c|c|}
\hline \multirow[t]{2}{*}{ Locality } & \multirow{2}{*}{$\begin{array}{l}\text { POZW no. of studied } \\
\text { samples }^{\mathrm{a}}\end{array}$} & \multicolumn{2}{|c|}{ Accession no. } \\
\hline & & rpoC1 & $\begin{array}{l}\operatorname{trn} \mathrm{H}- \\
p s b \mathrm{~A}\end{array}$ \\
\hline
\end{tabular}

C. sphagnicola f. sphagnicola

NW Poland, Pomorskie Province, peat mat in the littoral zone of Lake Wałachy near $\quad$ 42284*

JF831177 JF776837 Wdzydze

NW Poland, Pomorskie Province, peat mat in the littoral zone of Lake Małe Katarzynki 42245

JF831176 JF776836

near Borowy Młyn

NW Poland, Pomorskie Province, Kościerzyna, Krwawe Doły peat bog near Lake Chądzie

NW Poland, Pomorskie Province, Lake Czyste peat bog near Płocice

$\mathrm{CS} 1402 *$

42266

NE Poland, Warmińsko-Mazurskie Province, peat mat in the littoral zone of Godle lake $\quad 41711^{*}$ near Ełk

C. sphagnicola f. paludosa

S Poland, Tatra Mts, E slope of Mt. Żółta Turnia, sphagnum-polytrichum hummocks, 1,687 m a.s.1.

S Poland, Tatra Mts, peat bog Toporowy Staw Wyżni, 1,110 m a.s.l.

S Poland, Tatra Mts, Pańszczyca Valley, peat bog Wielka Pańszczycka Młaka, 1,274 m a.s.l.

S Poland, Tatra Mts, N slope of Mt Ornak, sphagnum-polytrichum hummocks, 1,700 m a.s.l.

C. azurea

S Poland, Tatra Mts, Sucha Woda Valley, Psia Trawka meadow, 1,183 m a.s.l.

SE Poland, Bieszczady Mts, W slope of Mt Rozsypaniec Wołosacki, 1,215 m a.s.l.

NE Poland, Jez. Godle lake near Ełk

C. integristipula

S Poland, Tatra Mts, Sucha Woda Valley, Psia Trawka meadow, 1,180 m a.s.l.

NE Poland, Warmińsko-Mazurskie Province, Mechacz Wielki peat bog

SE Poland, Bieszczady Mts, W slope of Mt Rozsypaniec Wołosacki, 1,214 m a.s.l.

C. neesiana

S Poland, Tatra Mts, N slope of Mt Ornak, sphagnum-polytrichum hummocks, 1,680 m a.s.1.

NE Poland, Warmińsko-Mazurskie Province, Mechacz Wielki peat bog

SE Poland, Bieszczady Mts, W slope of Mt Rozsypaniec Wołosacki, 1204 m a.s.l.

C. suecica

S Poland, Beskid Żywiecki Mts, Mt Babia Góra, 1,190 m a.s.l.

41174

JF831169 JF776829

$41148 *$

42277*

$41722 d^{*}$

JF831180 JF776840

JF831178 JF776838

JF831179 JF776839

JF831171 JF776831

JF831170 JF776830

JF831172 JF776832

41746

JF831183 JF776843

41949

JF831181 JF776841

41748

JF831182 JF776842

CI1401

JF831187 JF776847

41730

41928

JF831188 JF776848

JF831189 JF776849

41731

JF831184 JF776844

41735

JF831185 JF776845

41927

JF831186 JF776846

39500

JF831175 JF776835

S Poland, Tatra Mts, stream near Lake Toporowy Staw Wyżni, 1,110 m a.s.l.

41727

JF831174 JF776834

SE Poland, Bieszczady Mts, Górna Solinka Valley, 772 m a.s.l.

41936

JF831173 JF776833

Tritomaria quinquedentata

S Poland, Tatra Mts, Jaworzynka Valley, 1,338 m a.s.l.

TQ705

JF831190 JF776850

S Poland, Tatra Mts, Miętusia Valley, 1,037 m a.s.l.

TQ1007

JF831191 JF776851

${ }^{a}$ The vouchers are deposited in the POZW Herbarium; * samples used for flow cytometry

(2004) and Buczkowska (2004a), and new detected alleles were denoted with subsequent numbers.

DNA extraction, PCR amplification and sequencing of chloroplast regions

Total genomic DNA was extracted from fresh material. Single stems were ground with silica beads in a FastPrep tissue disruptor for $20 \mathrm{~s}$ and subsequently processed using the DNeasy ${ }^{\circledR}$ Plant Mini Kit (Qiagen), following the manufacturer's protocol. Extracted DNA samples were stored at $-20^{\circ} \mathrm{C}$. For the amplification and sequencing of trnH-psbA and rpoC1, we used the primers of Sang et al. (1997) and from the Royal Botanical Garden in Kew website. The chloroplast regions were amplified in a volume of $25 \mu \mathrm{l}$ containing $20 \mathrm{mM}\left(\mathrm{NH}_{4}\right) \mathrm{SO}_{4}, 50 \mathrm{mM}$ Tris$\mathrm{HCl}\left(\mathrm{pH} 9.0\right.$ at $25^{\circ} \mathrm{C}$ ), $1.5 \mathrm{mM} \mathrm{MgCl}, 1 \mu \mathrm{BSA}, 200 \mu \mathrm{M}$ each, dATP, dGTP, dCTP, dTTP, $1.0 \mu \mathrm{M}$ of each primer, 
1 unit of Taq polymerase (Novazym, Poznań, Poland) and $1 \mathrm{ml}$ of DNA solution. The reaction was processed at $94^{\circ} \mathrm{C}$ for $1 \mathrm{~min}$ followed by 30 cycles at $94^{\circ} \mathrm{C}$ for $1 \mathrm{~min} ., 56^{\circ} \mathrm{C}$ for $1 \mathrm{~min}$. and $72^{\circ} \mathrm{C}$ for $1.5 \mathrm{~min}$., with a final extension step of $72^{\circ} \mathrm{C}$ for $5 \mathrm{~min}$. Finally, $5 \mu \mathrm{l}$ of the amplification products was visualized on $1.5 \%$ agarose gel with ethidium bromide staining. Purified PCR products were sequenced in both directions using the ABI BigDye 3.1 Terminator Cycle Kit (Applied Biosystems) and were then visualized using an ABI Prism 3130 Automated DNA Sequencer (Applied Biosystems).

\section{Flow cytometry}

Several (about 20-30) stems (gametophytes) were ground in a mortar with 2-ml nuclei isolation buffer NIM-DAPI (NPE Systems, Pembroke Pines, Fl) and $100 \mu \mathrm{l}$ DNA reference calibrator. The suspension with nuclei was filtered through a 30- $\mu \mathrm{m}$ nylon filter. The fluorescence of the nuclei for each sample was measured after $10 \mathrm{~min}$ of incubation using Cell Lab Quanta SC flow cytometer, equipped with a mercury arc lamp. Chicken red blood cells (CRBC) were used as internal standard, because this standard has a convenient amount of DNA related to liverworts. DNA content was measured assuming that CRBC contained 2.33 pg DNA/2C (Baird et al. 1994). Data were analyzed by means of the Quanta SC software. Three different samples of each form of $C$. sphagnicola were measured.

\section{Data analysis}

For isozyme data allele frequencies, the percentage of polymorphic loci $(\mathrm{P})$ and mean numbers of alleles per locus (A) were calculated for each form. For estimation of genetic variation, gene diversity statistics (Nei 1973, 1978) were calculated. Nei's (1978) genetic distance (D) was estimated between the populations of each form and between the forms. The resulting distance matrix was used to infer an UPGMA dendrogram. Analyses were performed using GenAlEx 6.3 (Peakall and Smouse 2005). The dendrogram was constructed using Mega 4.1 (Tamura et al. 2007). It is difficult to calculate the genetic distance between species of different ploidy levels. In order to compute the distance between the two studied forms, genotypes of the haploid form were treated as homozygotes of the diploid data format, and codominant options of GenAlEx were used.

Electropherograms of DNA sequences were edited and assembled using Sequencher 4.5 (Genecodes Inc.). The assembled sequences were aligned manually with BioEdit 7 (Hall 1999). Regions of ambiguous alignment and incomplete data (i.e., at the beginning and end of sequences) were excluded from the analyses. Gaps were excluded from all phylogenetic analyses. Phylogenetic analyses were conducted using maximum parsimony (MP) as implemented in MEGA 4.1. For parsimony analyses, we applied branch and bound search as implemented in MEGA 4.1. Statistical significance of clades within inferred trees was evaluated using the bootstrap method (Felsenstein 1985) with 2,000 replicates.

Incongruence between the $r p o \mathrm{C} 1$ and $\operatorname{trn} \mathrm{H}-p s b \mathrm{~A}$ data was assessed by comparing clade support on the consensus MP tree. For example, if species A was included in clade A with significant bootstrap support based on interference in the $r p o \mathrm{C} 1$ region, but resolved as a member of clade $\mathrm{B}$ with significant support based on the trn $\mathrm{H}-p s b \mathrm{~A}$ region, the phylogenetic trees based on these loci were considered incongruent. To identify incongruence in the phylogenetic signal, we used the $70 \%$ bootstrap criterion. Since incongruence was not observed, the rpo $\mathrm{C} 1$ and $t r n \mathrm{H}-p s b \mathrm{~A}$ data sets were combined for subsequent phylogenetic analyses. As another measure of distinctiveness, the number of fixed nucleotide differences among taxa was estimated for all pairwise combinations of species using the Sites program (Hey and Wakeley 1997).

\section{Results}

Isozyme analysis

The ten putative loci in seven enzyme systems were consistently resolved in the studied populations of $C$. sphagnicola. The examined forms: $C$. sphagnicola $\mathrm{f}$. sphagnicola and $C$. sphagnicola f. paludosa differ in respect to seven (Got, Est-1, Est-2, Gdh, Pgd, Pgm and Me) out of ten studied isozyme loci. The following alleles were diagnostic for $C$. sphagnicola f. sphagnicola: Got allele 1, Gdh allele 1, Pgd-2 allele 4, Pgm allele 5 and $M e$ phenotype 1, and for C. sphagnicola f. paludosa: Got alleles 34, Est-2 allele 2, Gdh alleles 14, Pgd-2 alleles 45, Pgm alleles 45 and $M e$ phenotype 2 (Fig. 1; Table 3). All isozyme phenotypes observed in typical form were single-banded, whereas in C. sphagnicola f. paludosa, four loci-Got, Pgd-2, Gdh and Pgm-showed a fixed heterozygous pattern (Fig. 1). Genetic variation within forms was low; two polymorphic loci (Mdh-2, Pgi) with two or three alleles were detected, respectively, in $C$. sphagnicola f. sphagnicola and C. sphagnicola f. paludosa. The gene diversity $\left(H_{\mathrm{T}}\right)$ based on allelic frequencies of all loci over all populations was 0.049 for $C$. sphagnicola f. sphagnicola and 0.048 C. sphagnicola f. paludosa. The mean number of alleles per locus was 1.20 and 1.30 , respectively.

Nei's genetic distance between $C$. sphagnicola f. sphagnicola and $C$. sphagnicola f. paludosa was equal to 0.472 and is lower than distances among each of the forms 


\section{$\begin{array}{ll}\text { C. sphagnicola } & \text { C. sphagnicola }\end{array}$ f. sphagnicola f. paludosa}

Est 1

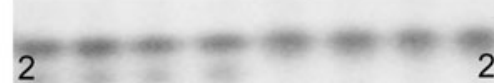

Est 2

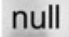

Got

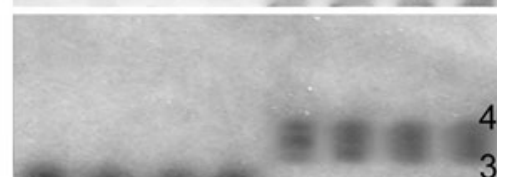

Pgd

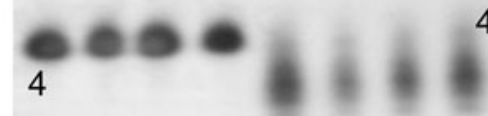

5

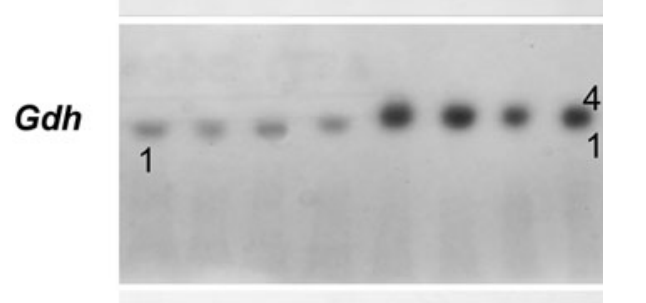

Pgm

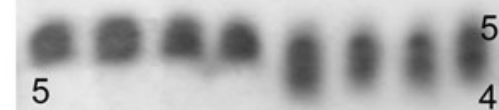

ME

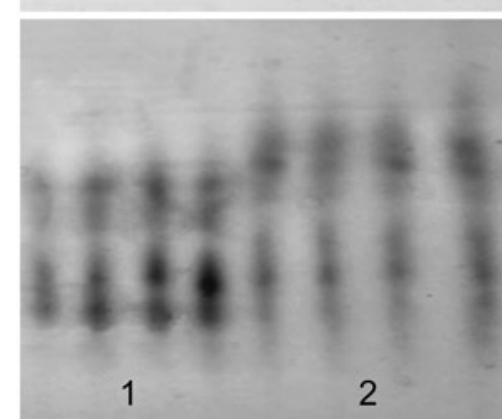

Fig. 1 Isozyme phenotypes of C. spagnicola f. sphagnicola and C. sphagnicola f. paludosa. Alleles were labeled according to Buczkowska et al. (2004) and Buczkowska (2004a). Newly detected alleles are denoted with the subsequent numbers

and C. azurea, the species used as a reference group (0.869 and 0.922 , respectively). Genetic distances among populations within C. sphagnicola $\mathrm{f}$. sphagnicola lay in the
Table 3 Allele frequencies in two studied forms of C. sphagnicola

\begin{tabular}{|c|c|c|c|}
\hline Locus & Allele & SPH & PAL \\
\hline Est-1 & 2 & 1.000 & 1.000 \\
\hline \multirow[t]{2}{*}{ Est -2} & Null & 1.000 & 0.000 \\
\hline & 2 & 0.000 & 1.000 \\
\hline \multirow[t]{3}{*}{ Got } & 1 & 1.000 & 0.000 \\
\hline & 3 & 0.000 & 0.500 \\
\hline & 4 & 0.000 & 0.500 \\
\hline \multirow[t]{2}{*}{$P g d-2$} & 4 & 1.000 & 0.500 \\
\hline & 5 & 0.000 & 0.500 \\
\hline \multirow[t]{2}{*}{$G d h$} & 1 & 1.000 & 0.500 \\
\hline & 4 & 0.000 & 0.500 \\
\hline \multirow[t]{2}{*}{ Pgm } & 4 & 0.000 & 0.500 \\
\hline & 5 & 1.000 & 0.500 \\
\hline$M d h-1$ & 1 & 1.000 & 1.000 \\
\hline \multirow[t]{2}{*}{$M d h-2$} & 1 & 0.808 & 0.874 \\
\hline & 4 & 0.192 & 0.126 \\
\hline \multirow[t]{3}{*}{$P g i$} & 1 & 0.013 & 0.025 \\
\hline & 2 & 0.894 & 0.859 \\
\hline & 3 & 0.093 & 0.116 \\
\hline \multirow[t]{2}{*}{$M e^{*}$} & 1 & 1.000 & 0.000 \\
\hline & 2 & 0.000 & 1.000 \\
\hline$N$ & & 151 & 199 \\
\hline
\end{tabular}

$N$ number of analyzed shoots, SPH C. sphagnicola f. sphagnicola, PAL C. sphagnicola f. paludosa. Alleles were labeled according to Buczkowska et al. (2004) and Buczkowska (2004a); new detected alleles are denoted with the subsequent numbers. * In $M e$ phenotypes were scored

range of $0.000-0.098$, with a mean equal to 0.022 , and within $C$. sphagnicola f. paludosa between 0.000 and 0.063 , with a mean value equal to 0.017 , similarly, within C. azurea (0.000-0.094, with a mean of 0.038) (Fig. 2). The UPGMA dendrogram based on Nei's genetic distances shows the grouping of studied populations of $C$. sphagnicola into two distinct clusters, the first including C. sphagnicola f. sphagnicola, and the second populations of $C$. sphagnicola f. paludosa, both clearly separated from C. azurea (Fig. 3). Differences observed in the isozyme pattern clearly indicate that $C$. sphagnicola comprises two genetically distinct entities.

\section{Flow cytometry}

The DNA content of $C$. sphagnicola f. sphagnicola and C. sphagnicola f. paludosa was determined (Fig. 4). Haploid species $C$. suecica $(n=9)$ was used as a reference species. Nuclei DNA content of both forms was calculated using a comparative ratio: $\mathrm{MC}_{\text {sample }} \times 2.33 / \mathrm{MC}_{\text {standard }}$, where $\mathrm{MC}$ indicates the mean channel of fluorescence. MC in C. sphagnicola f. sphagnicola was 110, in C. sphagnicola 


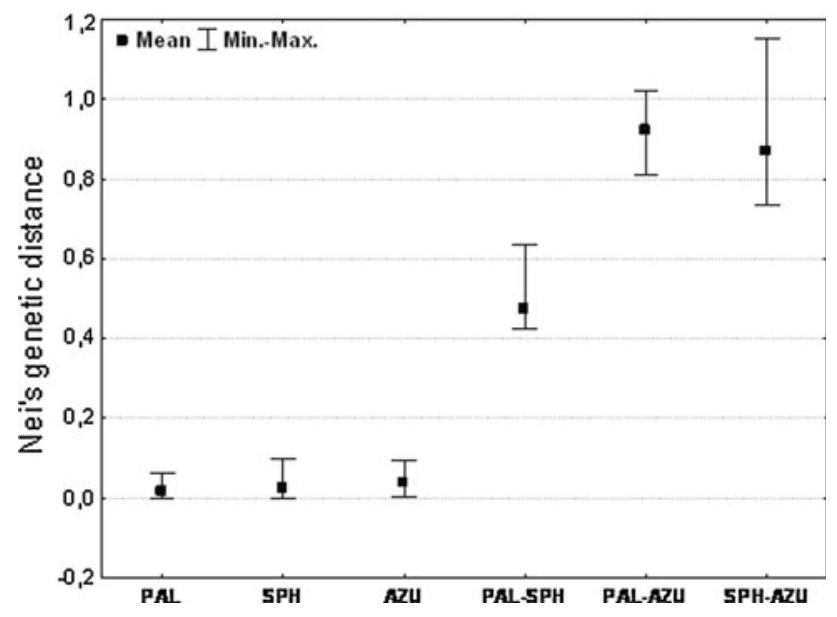

Fig. 2 Diagram showing the range of Nei's (1978) genetic distance based on isozyme data among populations of $C$. sphagnicola $\mathrm{f}$. paludosa, $C$. spagnicola $\mathrm{f}$. sphagnicola and $C$. azurea and between each examined pair of species

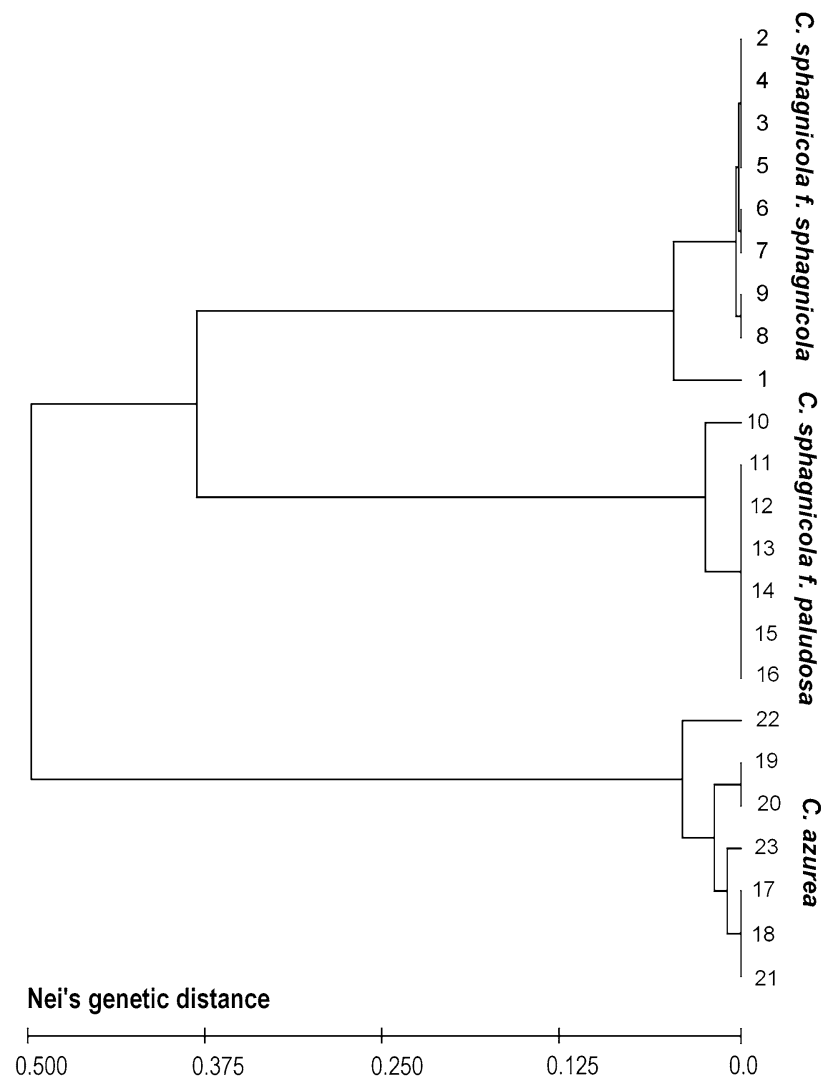

Fig. 3 UPGMA dendrogram of the studied populations of $C$. spagnicola f. sphagnicola, C. sphagnicola f. paludosa and C. azurea based on isozyme data

f. paludosa 181.6 and in C. suecica 119.1. The CRBC mean channel was 404, 376 and 420, respectively. The DNA content in examined samples was $0.634 \mathrm{pg} /$ nucleus in C. sphagnicola f. sphagnicola, $1.125 \mathrm{pg} /$ nucleus in
C. sphagnicola f. paludosa and $0.661 \mathrm{pg} /$ nucleus in C. suecica. The measurements were repeated three times for each sample, and the SD was 0.002, 0.005 and 0.003, respectively. The nuclear DNA content indicates that examined forms differ in ploidy level: $C$. sphagnicola f. sphagnicola is haploid, and C. sphagnicola f. paludosa is a diploid form.

\section{DNA sequencing}

The length of the trn $\mathrm{H}-p s b \mathrm{~A}$ spacer ranged from $222 \mathrm{bp}$ in the outgroup taxon Tritomaria to $225 \mathrm{bp}$ in the most samples of Calypogeia. Infraspecific length variation was noted in C. sphagnicola f. paludosa (224-225 bp), C. suecica (224-225 bp) and C. integristipula (224-225 bp). No substitutions were observed in the trnH-psbA sequences at the intraspecific level. The length of the sequenced rpoC1 region was constant across all analyzed specimens (641 bp). Among analyzed species, the highest intraspecific variation was observed in $C$. sphagnicola f. paludosa (11 substitutions). Much lower variation was found in C. integristipula (4 substitutions), C. azurea (2) and C. neesiana (2).

The total length of the aligned $t r n \mathrm{H}-p s b \mathrm{~A}$ spacer was 230 base pairs, including indels, with 52 variable and parsimony informative sites. The aligned rpoC1 data set contained 641 base pairs. The rpoC1 data set contained 108 parsimony informative characters and 9 variable, but uninformative characters. A maximum parsimony (MP) analysis resulted in 125 most parsimonious trees [length 191, consistency index (CI) 0.9066, retention index (RI) 0.9393]. The strict consensus tree with bootstrap values for supported nodes is presented in Fig. 5. The genus Calypogeia clade was well supported with bootstrap values of $99 \%$. Because each species forms a well-supported clade with bootstrap support ranging from $81 \%$ in case of C. sphagnicola f. sphagnicola to $99 \%$ in C. azurea, C. integristipula, $C$. nessiana and $C$. suecica, the analyzed data set does not provide much information about genetic relationships among species. Only two species form a common clade, $C$. integristipula and $C$. neesiana, with bootstrap support $87 \%$.

The non-coding trnH-psbA spacer revealed fixed nucleotide differences for every pair of species. Their number for a pair of Calypogeia taxa ranged from 3 (C. sphagnicola and C. integristipula, C. integristipula and C. neesiana) to 7 (C. sphagnicola f. paludosa and C. neesiana, C. sphagnicola f. paludosa and $C$. suecica). The numbers of fixed nucleotide differences between the studied Calypogeia species and outgroup species of Tritomaria were significantly higher (45-48). The number of nucleotide pairwise differences in the coding $r p o \mathrm{C} 1$ region between the studied Calypogeia species ranged from 2 (C. azurea 
Fig. 4 Histograms of relative DNA content obtained after a flow cytometric analysis of DAPI-stained nuclei of: a internal standard, b $C$. suecica, c C. spagnicola $\mathrm{f}$. sphagnicola and $\mathbf{d}$

C. sphagnicola $\mathrm{f}$. paludosa
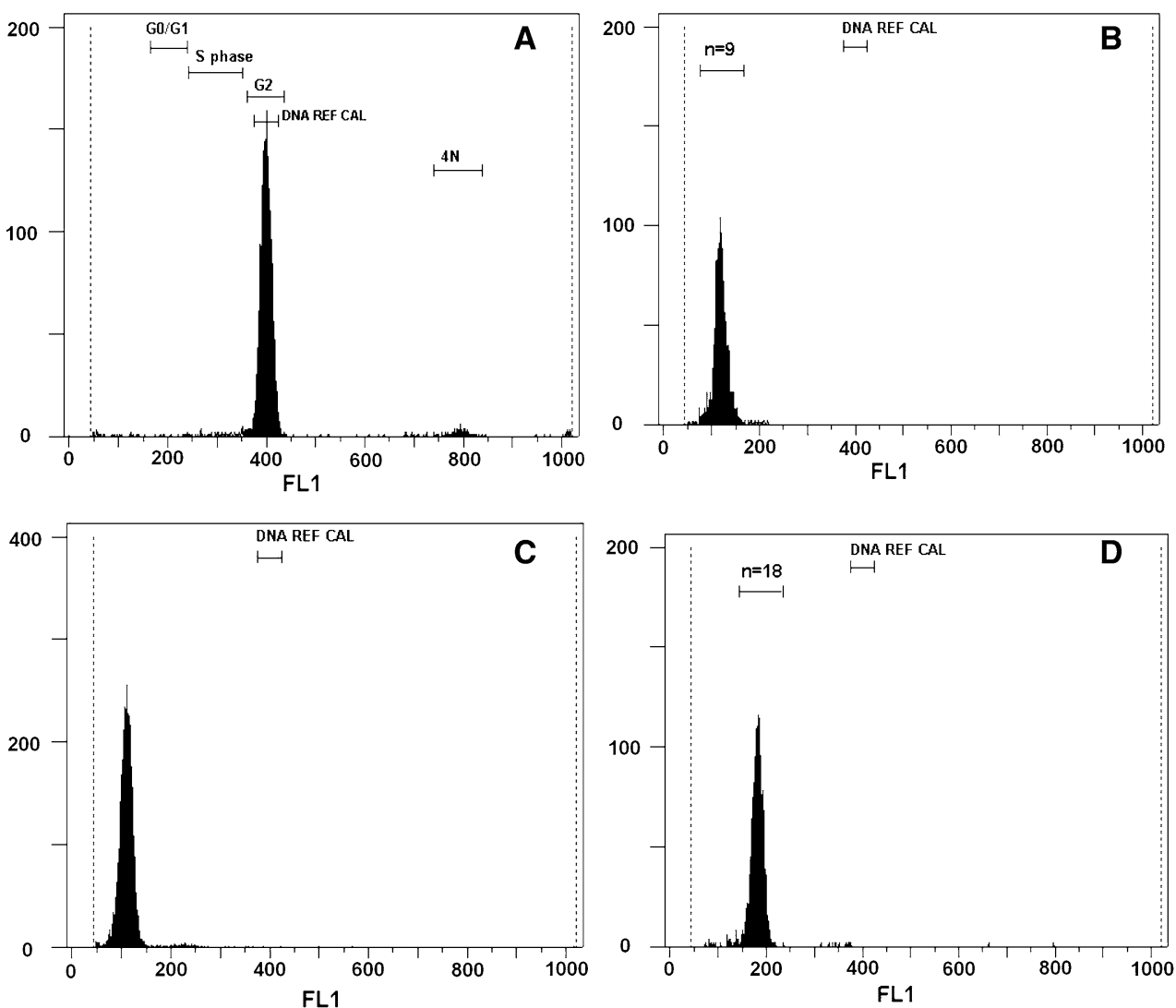

and C. sphagnicola f. sphagnicola) to 21 (C. neesiana and C. suecica). Calypogeia species differ from the outgroup Tritomaria in 78-86 sites depending on species (Table 4). Between the studied forms of $C$. sphagnicola, five fixed nucleotide differences in $t r n \mathrm{H}-p s b \mathrm{~A}$ and three in the $r p o \mathrm{C} 1$ region were found.

\section{Discussion}

Complementing classical taxonomy of liverworts, based on morphology, with characters inferred from genetic markers has revealed numerous examples of earlier unrecognized species, suggesting that the number of liverwort species is still underestimated (e.g., Shaw 2001; Bạczkiewicz et al. 2008; Heinrichs et al. 2009, 2010). Results of the present study show that $C$. sphagnicola is another example of a liverwort species that was too broadly defined on the basis of morphological criteria.

Our results support the hypothesis that the two examined forms of $C$. sphagnicola represent genetically distinct species. Congruence of isozyme, flow cytometry and DNA sequence data strongly suggests that the two forms of C. sphagnicola should be recognized as distinct species. The genetic distance between these two forms $(D=0.472)$ estimated on the basis of ten isozyme loci is comparable, or

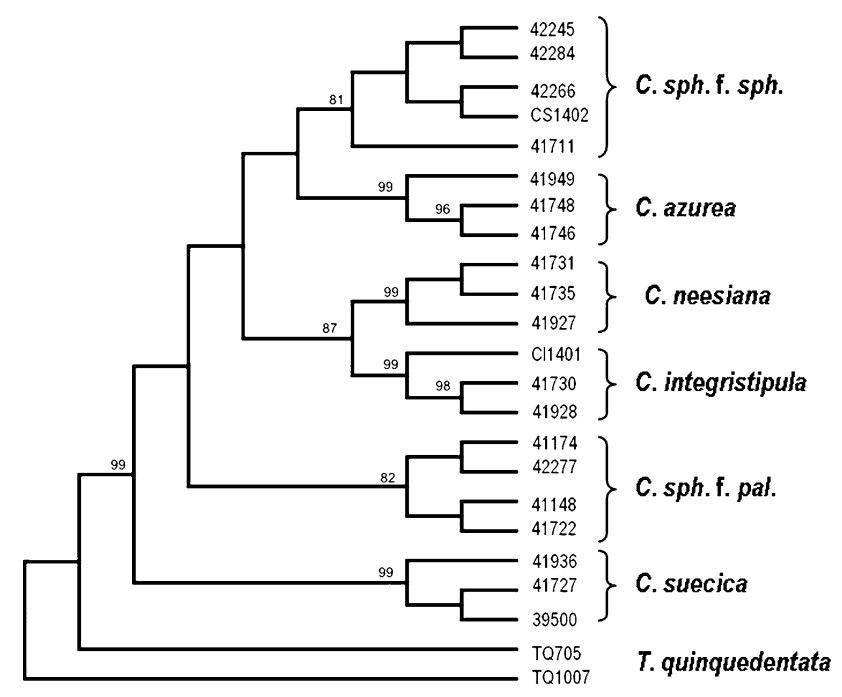

Fig. 5 Strict consensus of 191 most parsimonious trees based on combined analysis of $r p o \mathrm{C} 1$ and $t r n \mathrm{H}-p s b \mathrm{~A}$ sequences. Bootstrap values above $70 \%$ are given above branches

even higher than the values found by Boisselier-Dubayle and Bischler (1998) between haploid and diploid cytotypes of Corsinia coriandrina (Sprengel) Lindberg $(I=0.667)$ or between liverwort of an allopolyploid origin, Porella baueri (Schiffn.) C. Jens., and its two parental species: $P$. platyphylla L.Pfeiff. $(I=0.802)$ and $P$. cordeana (Hüb.) 
Table 4 Fixed nucleotide differences among studied Calypogeia species (trnH-psbA above and rpoC1 below)

\begin{tabular}{|c|c|c|c|c|c|c|c|}
\hline & T. quinquedentata & C. integristipula & C. suecica & $\begin{array}{l}\text { C. sph. } \\
\text { f. sphagnicola }\end{array}$ & C. neesiana & $\begin{array}{l}\text { C. sph. } \\
\text { f. paludosa }\end{array}$ & C. azurea \\
\hline T. quinquedentata & - & 47 & 46 & 47 & 48 & 45 & 48 \\
\hline C. integristipula & 86 & - & 5 & 3 & 3 & 6 & 5 \\
\hline C. suecica & 80 & 18 & - & 4 & 6 & 7 & 4 \\
\hline C. sphagnicola $f$. sphagnicola & 79 & 16 & 7 & - & 4 & 5 & 4 \\
\hline C. neesiana & 85 & 19 & 21 & 16 & - & 7 & 6 \\
\hline C. sphagnicola $f$. paludosa & 78 & 15 & 6 & 3 & 17 & - & 5 \\
\hline C. azurea & 80 & 18 & 9 & 2 & 18 & 5 & - \\
\hline
\end{tabular}

Bold indicates the number of differences between the studied form of $C$. sphagnicola

Moore $(I=0.738$; Boisselier-Dubayle et al. 1998a); the above values of genetic identities are the equivalent of genetic distance $0.405,0.221$ and 0.304 , respectively (according to formula $D=-\ln I$ ).

Fixed alleles diagnostic for each form were found in seven loci, among others, in Got, Est and Gdh, which had already been recognized as good diagnostic markers for Calypogeia species (Buczkowska et al. 2004). These loci have been acknowledged as diagnostic markers in many studies (e.g., Boisselier-Dubayle et al. 1998a; Bączkiewicz and Buczkowska 2005). Isozyme patterns of Got and Est-1 observed in the present study in the form C. sphagnicola $\mathrm{f}$. paludosa were the same as previously detected for C. sphagnicola (Buczkowska et al. 2004), whereas isozyme phenotypes revealed in the form $C$. sphagnicola $\mathrm{f}$. sphagnicola have not been found so far in any of the formerly studied Calypogeia species. Unfortunately, a previous isozyme study did not reveal genetic diversity of C. sphagnicola, because all samples originated from mountain populations, and thus only one form (C. sphagnicola $\mathrm{f}$. paludosa) was analyzed. The present study confirms the allopatric distribution of both forms in Poland as noted by Szweykowski (2006). Plants with genotypes characteristic of $C$. sphagnicola f. sphagnicola occur exclusively in the northern part of the country on raised peat bogs and peat mats in the littoral zone of dystrophic lakes. Plants classified as $C$. sphagnicola $\mathrm{f}$. paludosa were found only in southern Poland (in the mountains). They are very rare at lower attitudes, growing on peat bogs, but frequent in the subalpine zone, growing on Sphagnum-Polytrichum hummocks in the upper part of north-facing slopes. No mixed samples occurred in any population.

Strong evidence for genetic distinctness of the studied forms of $C$. sphagnicola was provided by the ploidy level. Nuclear DNA content of $C$. sphagnicola $\mathrm{f}$. sphagnicola was about two times lower compared to $C$. sphagnicola f. paludosa, whose chromosome number was previously determined as $n=18$. C. sphagnicola f. sphagnicola had a similar DNA content to $C$. suecica, a species with the haploid ( $n=9$ ) chromosome number (Buczkowska et al. 2004). This result indicates that the haploid condition separates $C$. sphagnicola f. sphagnicola from the diploid C. sphagnicola f. paludosa. The different ploidy level leads to reproductive isolation; thus, the haploid and diploid cytotypes should be treated as distinct species. The ploidy level of both $C$. sphagnicola forms was in an agreement with their isozyme pattern. In the diploid $C$. sphagnicola $\mathrm{f}$. paludosa at four (Got, Gdh, Pgd and Pgm) of the ten studied loci, fixed heterozygosity was observed, whereas in the typical form all isozyme loci had single-banded phenotypes. The results confirmed the allopolyploid origin of C. sphagnicola f. paludosa was initially suggested only on the basis of the Got isozyme (Buczkowska et al. 2004). A homogeneous pattern of fixed heterozygosity in all analyzed populations suggests that the allopolyploid species most probably has arisen once, in one hybridization event. Alleles in some isozyme loci indicated that $C$. sphagnicola f. sphagnicola could be one of the supposed parental species; however, not all alleles of the haploid form correspond to the alleles with the fixed heterozygosity of the polyploid. Except for $M e$, whose multi-banded pattern is difficult to interpret genetically, one allele (Got allele 1) is clearly in conflict with the hypothesis of $C$. sphagnicola f. sphagnicola as the supposed parental species. The second progenitor of the diploid form of $C$. sphagnicola could not be indicated at the moment because not all European species (C. arguta and C. azorica) have been examined yet. Moreover, present-day geographic distribution of the progenitor and derivatives species could not overlap, as was shown in the case of another polyploid liverwort, Reboulia hemisphaerica (Boisselier-Dubayle et al. 1998b). Thus, answering the question about the progenitors of the allopolyploid form of $C$. sphagnicola requires further studies of species from a wider range of geographic distribution since the genus comprises about 90 described species (Schuster 1969). An additional argument supporting the hypothesis that the haploid form could be one of the putative parental species comes from the results of SCAR 
markers (sequence characterized amplified region), which were previously developed for Calypogeia species on the basis of the ISSR method (Buczkowska and Dabert 2011). Two products of different sizes were amplified by the markers using the Cal02 primer pair in C. sphagnicola

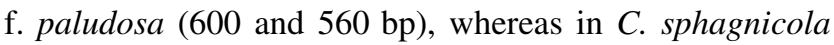
f. sphagnicola only one product of $560 \mathrm{bp}$ was present. Polyploidization is considered one of the most important mechanisms of species speciation in plants-between 30 and $70 \%$ of angiosperm, 4.6-10.3\% of liverworts and $6.4-18.6 \%$ of moss species have a polyploid origin (Stebbins 1971; Såstad 2005). Isozyme and molecular data provide evidence that allopolyploid species might be more frequent in liverworts than was previously presumed (e.g., Boisselier-Dubayle and Bischler 1998; Boisselier-Dubayle et al. 1998a, b; Fiedorow et al. 2001; Buczkowska et al. 2004). Data concerning the ploidy level in bryophytes are still incomplete as chromosome counting in some species is very difficult. Flow cytometry has proven to be helpful for the determination of the ploidy level in bryophyte species (Śliwińska et al. 2000; Ricca et al. 2008; Temsch et al. 2010).

Further evidence supporting species rank for the present-day forms of $C$. sphagnicola arose from a phylogenetic analysis based on chloroplast $r p o \mathrm{C} 1$ and $\operatorname{trn} \mathrm{H}-p s b \mathrm{~A}$ regions. C. sphagnicola f. sphagnicola is clearly separated from $C$. sphagnicola f. paludosa with high bootstrap support. Moreover, both forms are distinct from other examined species of the genus Calypogeia. Samples of C. sphagnicola were grouped into two distinct clades, which conform with the results inferred from isozyme markers. The phylogenetic analysis revealed a closer relationship between C. sphagnicola f. sphagnicola and C. azurea than between the present-day forms of $C$. sphagnicola. Noteworthily, C. sphagnicola f. paludosa formed a separate, well-supported clade. It suggests that the chloroplasts of C. sphagnicola f. paludosa were not inherited from C. sphagnicola f. sphagnicola, but rather from the other unknown parental taxon. The number of fixed nucleotide differences between the forms in the analyzed sequences is comparable to the number of differences between each of the forms and $C$. azurea or $C$. integristipula, which are well-known and accepted species. In the noncoding region $t r n \mathrm{H}-p s b \mathrm{~A}$, five fixed differences were detected between the studied forms; the same number of mutations was noted between the pairs of unequivocally different species: C. integristipula and C. azurea, C. integristipula and $C$. suecica, and $C$. azurea and $C$. suecica. The similar number of nucleotide differences in this chloroplast region was reported by Sawicki et al. (2010) for moss species from the subgenus Phaneroporum Delogne and the genus Zygodon Hook. \& Taylor or by Hedderson and Zander (2007) for the species Triquetrella Müll.Hal. Fixed nucleotide differences between the studied forms were also detected in the coding region rpoC1; however, the number of mutations was lower than between other pairs of accepted species of Calypogeia. The chloroplast rpoC1 and $t r n \mathrm{H}-p s b \mathrm{~A}$ sequences are commonly applied in molecular taxonomy and phylogenetic studies of bryophytes (Wilson et al. 2007). These chloroplast regions are proposed as a potential candidate for plastid barcoding loci in mosses and liverworts (Liu et al. 2010). According to Hollingsworth et al. (2009), rpoC1 and trnH-psbA were the most universal loci and amplified well across all studied species of the liverwort genus Asterella s.l. However, the locus rpoC1 has relatively low levels of species discrimination. Our results showed that both regions also worked well in the Calypogeia genus.

Two clades of $C$. sphagnicola identified in our study correspond to morphologically described forms of the species (Schuster 1969). The clade identified as C. sphagnicola $\mathrm{f}$. sphagnicola comprises small plants with abundant gemmiparous shoots, spherical and undivided, or, very rarely, is composed of 2-4 segment oil bodies (5-6 $\mu \mathrm{m}$ in diameter). Plants from a clade of C. sphagnicola f. paludosa are more robust and always without gemmae. They also are bigger and usually divided into several (5-9) segment oil bodies $(4-6 \times 4-9 \mu \mathrm{m})$. Biometrical analysis based on genetically determined material confirmed morphological differences, and the forms differ statistically significantly in respect to 34 quantitative morphological traits, e.g., the width and length of leaves, width of underleaves, length of stem internodes (between two adjacent underleaves) as well as cell size of underleaf and stem (Buczkowska et al. 2009). However, the quantitative traits are less reliable; therefore, species delimitation on the morphological disparities only may be difficult. The best diagnostic features are oil body characters and the presence or absence of gemmiparous shoots. Plants in the present study regarded as $C$. sphagnicola $\mathrm{f}$. sphagnicola morphologically correspond to the syntype specimen of C. sphagnicola from the UPS Herbarium (B-511887, Sweden, in prov. Skåne, ad Hörby, in sphagneto repens, J. Persson, June 1901) cited by Arnell (1902) in the protolog of the species. Plants of the syntype were small (width of shoots ranges from 990 to $1,170 \mu \mathrm{m}$, on average $1,070 \mu \mathrm{m}$ ) with gemmiparous shoots; broadly ellipsoidal gemmae were 2 -celled $(16 \times 23 \mu \mathrm{m})$. We are not yet able to understand the morphological variation of $C$. paludosa; the plants investigated so far do not exactly match the morphology of Warnstorf (1906) type material (S Herbarium: B20850-Berlin, Moor sűdlich an der Chaussee ErknerGottesbrück zwischen Sphagnum, E. Schultz, 23.01.1906 and B20841-K1. Pankow am Cressinsee zwischen Sphagnum, Jaap, 04.08.1898). Plants of the type specimens differ from the studied diploid form in underleaf shape, 
which had a broadly rounded sinus and often angulation on the lobes' external margins. Extension of sampling and inclusion of plants from other parts of the range are necessary to arrive at a final conclusion on the identity of the diploid entity. Therefore, the name of the diploid form is only provisional, based on Schuster's (1969) determination key.

\section{Conclusion}

The two present-day forms of $C$. sphagnicola are reproductively isolated because of differences in ploidy level and allopatric distribution: $C$. sphagnicola f. sphagnicola is haploid, whereas $C$. sphagnicola f. paludosa is a diploid form. The haploid form corresponds to the syntype specimen of $C$. sphagnicola, but the name of the diploid form was used only temporarily. A fixed heterozygous pattern of four isozyme loci indicated an allopolyploidal origin of the diploid form with the haploid form $C$. sphagnicola f. sphagnicola as one of the putative progenitors. The phylogenetic analysis based on chloroplast rpoC1 and trnH-psbA regions supports species rank for the presentday forms and suggests that the chloroplasts of $C$. sphagnicola f. paludosa were not inherited from C. sphagnicola f. sphagnicola but rather from the other unknown parental taxon.

Acknowledgments This work was financially supported by grant no. N303 344235 from the Polish Ministry of Science and Higher Education. We thank the Directors of the Tatra National Park and the Bieszczady National Park for their support provided during the fieldwork, and Patrycja Gonera for help in the laboratory. The authors thank Jochen Heinrichs and two anonymous reviewers for helpful comments on an earlier draft. We also wish to thank the curators of the herbaria: UPS, LD and S for the loan of specimens.

Open Access This article is distributed under the terms of the Creative Commons Attribution Noncommercial License which permits any noncommercial use, distribution, and reproduction in any medium, provided the original author(s) and source are credited.

\section{References}

Arnell W (1902) Novae species generis Kantiae. Rev Bryol 29:26-32 Baczkiewicz A, Buczkowska K (2005) Genetic variability of the Aneura pinguis complex (Hepaticae) in central and western Europe. Biological Lett 42:61-72

Bączkiewicz A, Sawicki J, Buczkowska K, Polok K, Zieliński R (2008) Application of different DNA markers in studies on cryptic species of Aneura pinguis (Jungermanniopsida Metzgeriales). Cryptogam Bryol 29:3-21

Baird WV, Estager AS, Well JK (1994) Estimating nuclear DNA content in peach and related diploid species using laser flow cytometry and DNA hybridization. J Am Soc Hort Sci 119:1312-1316
Bischler H, Boisselier-Dubayle MC (2000) New approaches to the systematics of liverworts. Nova Hedwigia 70:37-44

Boisselier-Dubayle MC, Bischler H (1998) Allopolyploidy in the thalloid liverwort Corsinia (Marchantiales). Bot Acta 111:490 496

Boisselier-Dubayle MC, Jubier MF, Lejeune B, Bischler H (1995) Genetic variability in the three subspecies of Marchantia polymorpha (Hepaticae): isozymes, RFLP and RAPD markers. Taxon 44:363-376

Boisselier-Dubayle MC, Lambourdiere J, Bischler H (1998a) The leafy liverwort Porella baueri (Porellaceae) is an allopolyploid. Pl Syst Evol 210:175-197

Boisselier-Dubayle MC, Lambourdiere J, Bischler H (1998b) Taxa delimitation in Reboulia investigated with morphological, cytological, and isozyme markers. Bryologist 101:61-69

Buczkowska K (2004a) Genetic differentiation of Calypogeia fissa (L.) Raddi (Hepaticae, Jungermanniales) in Poland. Pl Syst Evol 247:187-201

Buczkowska K (2004b) The genus Calypogeia Raddi (Hepaticae Jungermnniales) in Poland biometrical analysis of morphological and anatomical variation. Nova Hedwigia 78:121-146

Buczkowska K, Bạczkiewicz A (2011) New taxon of the genus Calypogeia (Jungermanniales Hepaticae) in Poland. Acta Soc Bot Pol 80(4). doi:10.5586/asbp.2011.039

Buczkowska K, Dabert M (2011) The development of species-specific SCAR markers for delimitation of Calypogeia species. J Bryol 33:291-299. doi:10.1179/1743282011Y.0000000029

Buczkowska K, Odrzykoski IJ, Chudzińska E (2004) Delimitation of some European species of Calypogeia Raddi (Hepaticae Jungermnniales) based on cytological characters of oil bodies and multienzyme phenotype. Nova Hedwigia 78:147-163

Buczkowska K, Bączkiewicz A, Sawicki J, Szczecińska M (2009) Genetic differentiation within Calypogeia sphagnicola (Jungermanniales Hepaticae) in Poland. Nowel Bryol (special issue): $34-42$

Damsholt K (2002) Illustrated flora of Nordic liverworts and hornworts. Nordic Bryological Society, Lund

Felsenstein J (1985) Confidence limits on phylogenies: an approach using the bootstrap. Evolution 39:783-791

Fiedorow P, Odrzykoski IJ, Szweykowski J, Szweykowska-Kulińska Z (2001) Phylogeny of the European species of the genus Pellia (Hepaticae, Metzgeriales) based on the molecular data from nuclear $t R N A^{\text {Leu }}$ (CAA) intergenic sequences. Gene 262:309-315

Gottlieb LD (1981) Electrophoretic evidence and plant populations. In: Reinhold L, Harborne JB, Swain T (eds) Progress in Phytochemistry vol. 7. Pergamon Press, Oxford, pp 1-46

Grolle R, Long DG (2000) An annotated check-list of the Hepaticae and Anthocerotae of Europe and Macaronesia. J Bryol 22:103140

Hall TA (1999) BioEdit: a user-friendly biological sequence alignment editor and analysis program for Windows 95/98/NT. Nucl Acids Symp Ser 41:95-98

Hedderson TA, Zander RH (2007) Triquetrella mxinwana a new moss species from South Africa with a phylogenetic and biogeographic hypothesis for the genus. J Bryol 29:151-160

Heinrichs J, Klugmann F, Hentschel J, Schneider H (2009) DNA taxonomy, cryptic speciation and diversification of the Neotropical-African liverwort, Marchesinia brachiata (Lejeuneaceae Porellales). Molec Phylog Evol 53:113-121

Heinrichs J, Hentschel J, Bombosch A, Fiebig A, Reise J, Edelmann M, Kreier HP, Schäfer-Verwimp A, Caspari S, Schmidt AR, Zhu RL, Konrat M, Shaw B, Shaw AJ (2010) One species or at least eight? Delimitation and distribution of Frullania tamarisci (L) Dumort s 1 (Jungermanniopsida Porellales) inferred from 
nuclear and chloroplast DNA markers. Molec Phylog Evol 56:1105-1114

Hey J, Wakeley J (1997) A coalescent estimator of the population recombination rate. Genetics 145:833-846

Hollingsworth ML, Clark AA, Forrest LL, Richardson J, Pennington RT, Long DG, Cowan R, Chase MW, Gaudeul M, Hollingsworth $P$ (2009) Selecting barcoding loci for plants: evaluation of seven candidate loci with species-level sampling in three divergent groups of land plants. Mol Ecol Res 9:439-457

Inoue H (1976) Chromosome studies in some Arctic hepatics. Bull Nat Sci Mus Tokyo Ser B 2:39-46

Kreier HP, Feldberg K, Mahr F, Bombosch A, Schmidt AR, Zhu RL, Konrat M, Shaw B, Shaw AJ, Heinrichs J (2010) Phylogeny of the leafy liverwort Ptilidium: cryptic speciation and shared haplotypes between Northern and Southern Hemispheres. Molec Phylog Evol 57:1260-1267

Liu Y, Yan HF, Cao T, Ge XJ (2010) Evaluation of 10 plant barcodes in bryophyte (Mosses). J Syst Evol 48:36-46

Müller K (1913-1916) Die Lebermoose Europas. In: Dr. L Rabenhorst's Kryptogamen Flora von Deutschland Österreich und der Schweiz. Verlag von Eduard Kummer, Leipzig

Müller K (1951-1958) Die Lebermoose Europas. In: Dr. L. Rabenhorst's Kryptogamen Flora von Deutschland, Österreich und der Schweiz. Akademische Verlagsgesellaschaft Geest \& Portig K-G, Leipzig

Nei M (1973) Analysis of gene diversity in subdivided populations. Proc Natl Acad Sci USA 70:3321-3323

Nei ME (1978) Estimation of average heterozygosity and genetic distance from a small number of individuals. Genetics 89:583-590

Newton M (1973) Chromosome studies in some British and Irish bryophytes, II. J Bryol 7:379-398

Peakall R, Smouse P (2005) Genalex 6: genetic analysis in Excel Population genetic software for teaching and research. Mol Ecol Notes 6:288-295

Ricca M, Beecher FW, Boles SB, Temsch E, Greilhuber J, Karlin EF, Shaw AJ (2008) Cytotype variation and allopolyploidy in North American species of the Sphagnum subsecundum complex (Sphagneceae). Am J Bot 95:1606-1620

Sang T, Crawford DJ, Stuessy TF (1997) Chloroplast DNA phylogeny reticulate evolution and biogeography of Paeonia (Paeoniaceae). Am J Bot 84:1120-1136

Såstad SM (2005) Patterns and mechanisms of polyploid formation in bryophytes. Regnum Vegetabile 143:317-334

Sawicki J, Plášek V, Szczecińska M (2010) Molecular studies resolve Nyholmiella (Orthotrichaceae) as a separate genus. J Syst Evol 48:183-194
Schuster RM (1969) The Hepaticae and Anthocerotae of North America east of the hundredth meridian vol. 2. Columbia University Press, New York

Shaw AJ (2001) Biogeographic patterns and cryptic speciation in bryophytes. J Biogeog 28:253-261

Śliwińska E, Krzakowa M, Melosik I (2000) Estimation of ploidy level in four Sphagnum species (Subsecunda section) by flow cytometry. In: Krzakowa M, Melosik I (eds) The variability in Polish populations of sphagnum taxa (Subsecunda section) according to morphological anatomical and biochemical traits. Bogucki Press SC, Poznań, pp 137-150

Stebbins GL (1971) Chromosomal evolution in higher plants. Edward Arnold, London

Szweykowska-Kulińska Z, Pacak A, Jankowiak K (2002) New DNA markers for discrimination between closely-related species and for the reconstruction of historical events; an example using liverworts. Cell Mol Biol Lett 7:403-416

Szweykowski J (2006) An annotated checklist of Polish liverworts. Biodiversity of Poland vol 4. W Szafer Institute of Botany Polish Academy of Sciences, Kraków

Szweykowski J, Krzakowa M (1979) Variation of four enzyme systems in Polish populations of Conocephalum conicum (L) Dumort (Hepaticae Marchantiales). Bull Acad Polon Sci Ser Sci Biol 27:37-41

Szweykowski J, Buczkowska K, Odrzykoński IJ (2005) Conocephalum salebrosum (Marchantiopsida Conocephalaceae) a new Holarctic liverwort species. Pl Syst Evol 253:133-158

Tamura K, Dudley J, Nei M, Kumar S (2007) MEGA4: molecular evolutionary genetics analysis (MEGA) software version 4.1. Mol Biol Evol 24:1596-1599

Temsch E, Greilhuber J, Krisai R (2010) Genome size in liverworts. Preslia 82:63-80

Wachowiak W, Bączkiewicz A, Chudzińska E, Buczkowska K (2007) Cryptic speciation in liverworts-a case study in the Aneura pinguis complex. Bot J Linn Soc 155:273-282

Warnstorf C (1906) Kryptogamenflora der Mark Brandenburg, vol 2. Verlag von Gebrüder Borntraeger, Leipzig

Wendel JE, Weeden NF (1989) Visualisation and interpretation of plant isozymes. In: Soltis DE, Soltis PS (eds) Isozymes in plant biology. Dioscorides Press, Portland Oregon, pp 4-45

Wilson R, Gradstein SR, Schneider H, Heinrichs J (2007) Unravelling the phylogeny of Lejeuneaceae (Jungermanniopsida): evidence for four main lineages. Molec Phylog Evol 43:270-282 